\title{
Heinrich event 4 characterized by terrestrial proxies in southwestern Europe
}

\author{
J. M. López-García ${ }^{1}$, H.-A. Blain ${ }^{2,3}$, M. Bennàsar ${ }^{2,3}$, M. Sanz ${ }^{4}$, and J. Daura ${ }^{4}$ \\ ${ }^{1}$ Gruppo di Ricerca di Paleobiologia e Preistoria. Dipartamento di Studi Umanistici, \\ Università degli Studi di Ferrara. C.so Ercole 1 d'Este 32, 44121 Ferrara, Italy \\ ${ }^{2}$ IPHES, Institut Català de Paleoecologia Humana i Evolució Social, C/Escorxador s/n, 43003 Tarragona, Spain \\ ${ }^{3}$ Àrea de Prehistòria, Universitat Rovira i Virgili (URV), Avinguda de Catalunya 35, 43002 Tarragona, Spain \\ ${ }^{4}$ Grup de Recerca del Quaternari, SERP, Dept. Prehistòria, H. Antiga i Arqueologia, Universitat de Barcelona, C/Montalegre, \\ 6, 08001 Barcelona, Spain
}

Correspondence to: J. M. López-García (lpzjmn@unife.it)

Received: 13 December 2012 - Published in Clim. Past Discuss.: 4 February 2013

Revised: 15 April 2013 - Accepted: 15 April 2013 - Published: 7 May 2013

\begin{abstract}
Heinrich event 4 (H4) is well documented in the North Atlantic Ocean as a cooling event that occurred between 39 and $40 \mathrm{Ka}$. Deep-sea cores around the Iberian Peninsula coastline have been analysed to characterize the $\mathrm{H} 4$ event, but there are no data on the terrestrial response to this event. Here we present for the first time an analysis of terrestrial proxies for characterizing the $\mathrm{H} 4$ event, using the small-vertebrate assemblage (comprising small mammals, squamates and amphibians) from Terrassa Riera dels Canyars, an archaeo-palaeontological deposit located on the seaboard of the northeastern Iberian Peninsula. This assemblage shows that the $\mathrm{H} 4$ event is characterized in northeastern Iberia by harsher and drier terrestrial conditions than today. Our results were compared with other proxies such as pollen, charcoal, phytolith, avifauna and large-mammal data available for this site, as well as with the general H4 event fluctuations and with other sites where $\mathrm{H} 4$ and the previous and subsequent Heinrich events (H5 and H3) have been detected in the Mediterranean and Atlantic regions of the Iberian Peninsula. We conclude that the terrestrial proxies follow the same patterns as the climatic and environmental conditions detected by the deep-sea cores at the Iberian margins.
\end{abstract}

\section{Introduction}

The Heinrich events have been generally defined, according to Cayre et al. (1999), by a decrease in $\delta^{18} \mathrm{O}$, peaks in magnetic susceptibility, an increase in the proportion of the foraminifer Neogloboquadrina pachyderma, as well as the appearance of IRD (iceberg rafted detritus). Of these events, Heinrich event 4 (H4), which occurred ca. $39-40 \mathrm{Ka}$, is one of the most abrupt climate cooling episodes, well recorded in sediment cores throughout the North Atlantic Ocean and the adjacent continents (Roche et al., 2004; Sepulchre et al., 2007). Deep-sea cores around the Iberian Peninsula coastline have been analysed to characterize the Heinrich event fluctuations (Cacho et al., 1999; Sánchez-Goñi et al., 2002; Sierro et al., 2005; Naughton et al., 2009, among others). Taking into account the recent data provided by these deep-sea core analyses, the $\mathrm{H} 4$ event can be characterized at the Iberian margins, according to Naughton et al. (2009), by two main phases: (1) a first phase marked by relatively wet and very cold atmospheric conditions; and (2) a second phase marked by an extreme continental dryness and cooler conditions. According to Sánchez-Goñi et al. (2002), moreover, there are differences between the data obtained by the deep-sea cores for the $\mathrm{H} 4$ event at the Mediterranean and the Atlantic margins of the Iberian Peninsula, the H4 event being more humid at the Atlantic than the Mediterranean margin. Furthermore, simulation models and pollen extrapolations from the deep-sea cores have been undertaken in order to observe the 


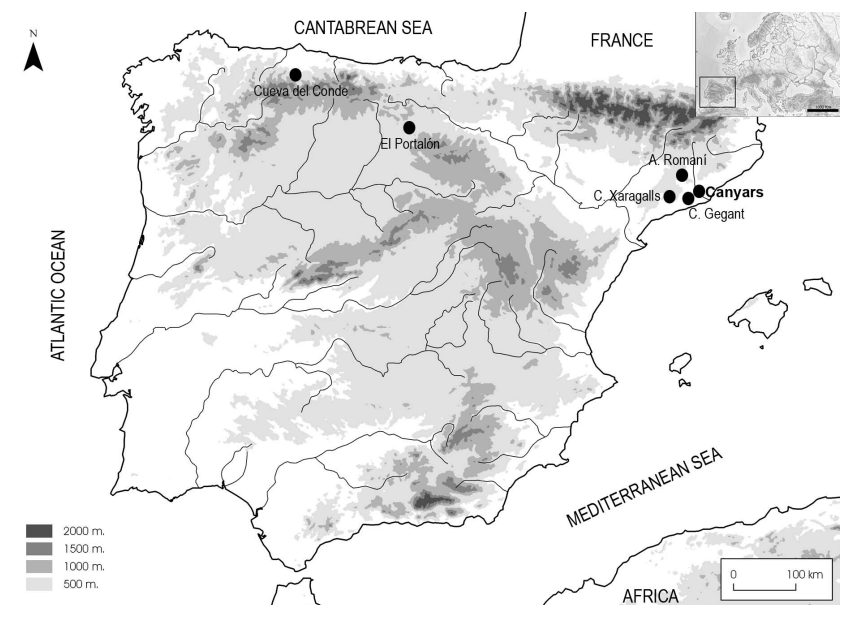

Fig. 1. Location of the sites mentioned in text in the Iberian Peninsula, including Canyars (Terrasses de la Riera dels Canyars).

terrestrial response to the $\mathrm{H} 4$ event in the Iberian Peninsula (Sánchez-Goñi et al., 2002; Sepulchre et al., 2007; Naughton et al., 2009; Fletcher and Sanchez-Goñi, 2008; Fletcher et al., 2010; Bout-Roumazille et al., 2007; Combourieu Nebout et al., 2002, among many others). Here we present for the first time a characterization of the environment and climate of the $\mathrm{H} 4$ event based on the small-vertebrate assemblage of the Terrasses de la Riera dels Canyars (henceforth, Canyars). Our results are compared with the pollen, charcoal, phytolith, avifauna and large-mammal data obtained for this site (Daura et al., 2013), as well as with the general H4 event fluctuations to see whether the phases detected by Naughton et al. (2009) can be observed for the Canyars data. They are also compared with data from other sites where $\mathrm{H} 4$ and the previous and subsequent Heinrich events ( $\mathrm{H} 5$ and $\mathrm{H} 3$ ) have been detected in the Mediterranean and Atlantic regions of the Iberian Peninsula, to observe whether or not the terrestrial proxies follow the same patterns as the climatic and environmental conditions detected by the deep-sea cores at the Iberian margins.

\section{Site description and chronology}

Canyars is a fluvial deposit located in the town of Gavà, some $20 \mathrm{~km}$ to the west of Barcelona, in Vall de la Sentiu, one of the creeks originating at the foot of the Garraf Massif that flows into the beaches of the Mediterranean seaboard. The site was discovered in 2005 (Daura and Sanz, 2009; Daura et al., 2013) by an amateur archaeologist (C. Valls) and completely excavated by the Grup de Recerca del Quaternari from June to November 2007.

Nowadays, Canyars is located in an abandoned gravelpit that remained active until the 1960s. Pleistocene fossils from the same area were already known. The first discovery from Vall de la Sentiu was an Upper Pleistocene palaeonto-

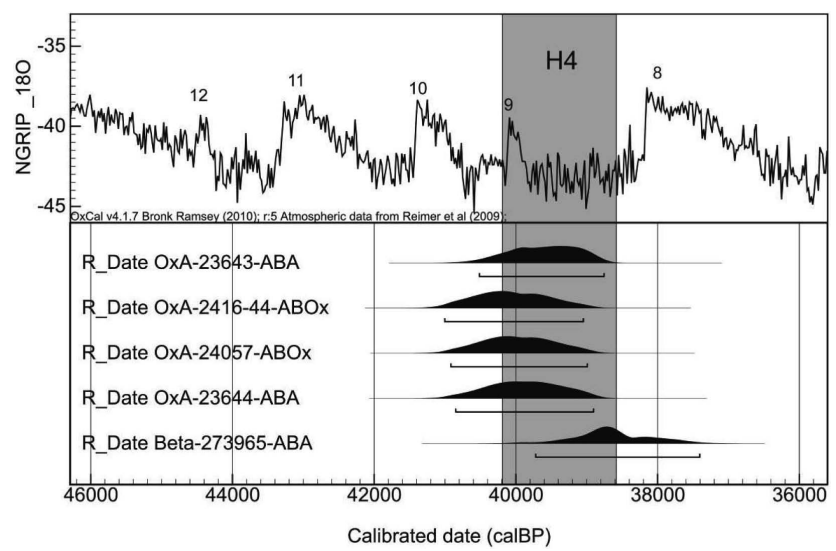

Fig. 2. Plot of the Canyars ${ }^{14} \mathrm{C}$ dates, calibrated with the Intcal09 curve (Reimer et al., 2009) and compared with the North Greenland Ice Core Project (NGRIP) $\delta^{18} \mathrm{O}$ ice-core record of Svensson et al. (2006) and Andersen et al. (2005), showing GI interestadials and Heinrich Event 4 according to Svensson et al. (2008) (prepared using OxCal vs. 4.1.7; Bronk Ramsey, 2009).

logical collection from an emplacement that is not known precisely (Villalta, 1953); another corresponds to an isolated proboscidean remains (cf. Mammuthus) from a different gravel-pit $700 \mathrm{~m}$ from Canyars (Daura and Sanz, 2009). Other palaeontological remains from adjacent valleys have been recovered in the course of archaeological survey excavations; Riera de Sant Llorenç has provided large-mammal remains, mainly Mammuthus, Coelodonta and Equus (Daura et al., 2013).

Canyars is located at the confluence of two creeks, Riera dels Canyars and Riera de Can Llong. The former is the main stream, and its distal part probably consisted of a floodplain crossed by channels, nowadays modified by farming activity (Daura et al., 2013). A total of 9 lithological units have been described, consisting of a poorly sorted and coarse-grained complex of gradational and incised fluvial deposits. Palaeontological remains come from the only archaeological unit (MLU, Middle Lutitic Unit), consisting of mudsupported gravel filling a well-defined palaeochannel (LDU, Lower Detritical Unit).

Several charcoal samples were collected for radiocarbon dating, with a ${ }^{14} \mathrm{C}$ dating result of $\sim 34.6{ }^{14} \mathrm{C}(\sim 39.6$ cal.) $\mathrm{Ka}$ (overall mean age estimate from four radiocarbon datings by Daura et al., 2013) (Table 1; Fig. 2).

\section{Material and methods}

\subsection{Small-vertebrate sorting and palaeontological study}

The small-vertebrate fossil remains used for this study consist mainly of disarticulated bone fragments and isolated teeth collected by dry and water screening. All the sediment was dry-screened using superimposed 5 and $0.5 \mathrm{~mm}$ 
Table 1. Radiocarbon dates from Canyars. Ages (BP, before present) are calibrated with the OxCal 4.1.7 software (Bronk Ramsey, 1995) using the IntCal09 curve (Reimer et al., 2009).

\begin{tabular}{|c|c|c|c|c|c|c|}
\hline Site Inventory & Material & Lab\# & Pre-treatment & $\delta 13 \mathrm{C}$ & AgeBP & $\operatorname{calBP}(2 \sigma)$ \\
\hline TC07-I-L24-MCV & $\begin{array}{l}\text { Charcoal } \\
\text { (Pinus sylvestris type) }\end{array}$ & Beta273965 & $\mathrm{ABA}$ & $-23.5 \%$ & $33800 \pm 350$ & $37405-39720$ \\
\hline TC07-I-L25-MCV & $\begin{array}{l}\text { Charcoal } \\
\text { (Pinus sylvestris type) }\end{array}$ & $\begin{array}{l}\text { OxA-23643 } \\
\text { OxA-2416-44 }\end{array}$ & $\begin{array}{l}\text { ABA } \\
\text { ABOx-SC }\end{array}$ & $\begin{array}{r}-23.0 \% 0 \\
-22.89 \%\end{array}$ & $\begin{array}{l}34540 \pm 330 \\
34980 \pm 350\end{array}$ & $\begin{array}{l}38756-40516 \\
39048-41004\end{array}$ \\
\hline TC07-I-L25-MCV & $\begin{array}{l}\text { Charcoal } \\
\text { (Pinus sylvestris type) }\end{array}$ & $\begin{array}{l}\text { OxA-23644 } \\
\text { OxA-24057 }\end{array}$ & $\begin{array}{l}\text { ABA } \\
\text { ABOx-SC }\end{array}$ & $\begin{array}{l}-23.35 \% \\
-22.77 \% \circ\end{array}$ & $\begin{array}{l}34810 \pm 360 \\
34900 \pm 340\end{array}$ & $\begin{array}{l}38904-40849 \\
38993-40916\end{array}$ \\
\hline
\end{tabular}

mesh screens during fieldwork, and $\sim 500 \mathrm{~kg}$ of the sample was water-sieved $(1.5-0.5 \mathrm{~mm})$ in the La Guixera laboratory (Castelldefels, Barcelona). The fossils were processed, sorted and classified at the Institut de Paleoecologia Humana y Evolució Social of the University Rovira i Virgili (Tarragona, Spain). The assemblage includes a total of 362 fragments, 182 of which were identified to genus or species level and correspond to a minimum number of 26 small vertebrates, representing at least 15 taxa (Table 2; Figs. 3, 4). The fragments were identified following the general criteria given by Furió (2007) for insectivores, Van der Meulen (1973) and Cuenca-Bescós et al. (2010) for rodents, and Bailon (1999), Sanchiz et al. (2002), Blain (2005, 2009) and Szyndlar (1984) for the herpetofauna. The specific attribution of this material rests principally on the best diagnostic elements: humerus, ilium, scapula and sacrum for anurans; jaws and vertebrae for lizards, vertebrae for snakes; mandible, maxilla and isolated teeth for shrews; isolated teeth and humerus for Talpidae; first lower molars for Arvicolinae; and isolated teeth for Apodemus sylvaticus and Eliomys quercinus. Moreover, the fossils were grouped using the minimum-numberof-individuals (MNI) method, by means of which we determined the sample (i.e. from each level) by counting the best diagnostic elements, taking into account, whenever possible, laterality and (for amphibians) sex.

\subsection{Palaeoenvironmental reconstruction}

In order to reconstruct the palaeoenvironment at Canyars, we use the method of habitat weightings (see Evans et al., 1981; Andrews, 2006), distributing each small-vertebrate taxon in the habitat(s) where it can be found at present in the Iberian Peninsula. Habitats are divided into five types (in accordance with Cuenca-Bescós et al., 2005, 2009; Blain et al., 2008; Rodriguez et al., 2011; López-García et al., 2010a, 2011a). These types are detailed as follows (Table 2): open dry: meadows under seasonal climate change; open humid: evergreen meadows with dense pastures and suitable topsoil; woodland: mature forest including woodland margins and forest patches, with moderate ground cover; water: areas along streams, lakes and ponds; rocky: areas with a suitable rocky or stony substratum. The "Ch1\&Ch2"
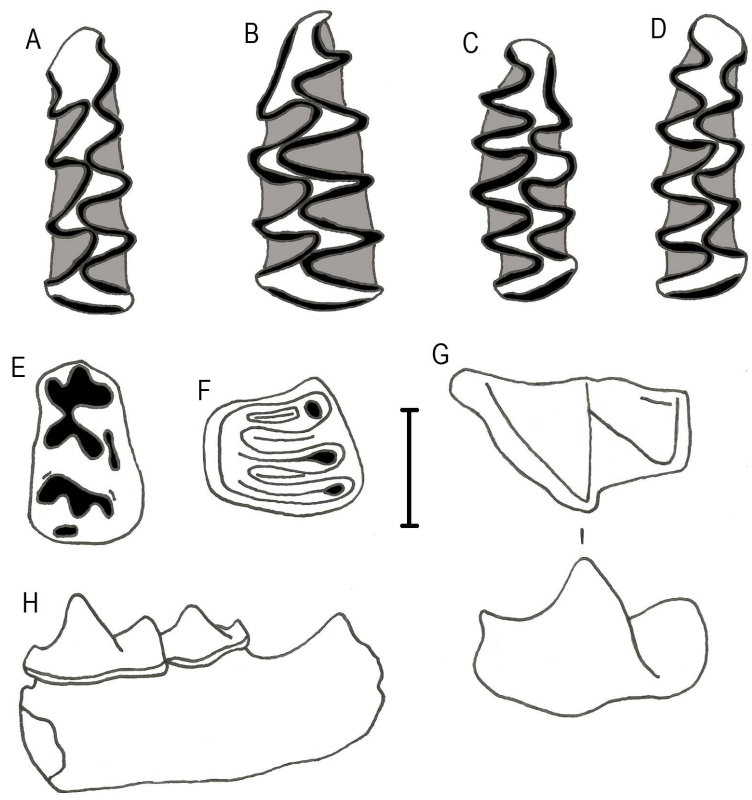

Fig. 3. Some small mammals from Canyars. A: first left lower molar (m1) Microtus (Terricola) duodecimcostatus (occlusal view); B: m1 left Microtus (Iberomys) cabrerae (occlusal view); C: m1 right Microtus agrestis (occlusal view); D: $\mathrm{m} 1$ right Microtus arvalis (occlusal view); E: m1 right Apodemus sylvaticus (occlusal view); F: m1 right Eliomys quercinus (occlusal view); G: third left lower molar (m3) Talpa europaea (occlusal and labial views); H: left mandible (m2-m3) Crocidura sp. Scale $1 \mathrm{~mm}$.

(chorotype) and "Ch3" data were obtained from the percentage representation of the MNI by classifying our taxa according to chorotypes established previously by Sans-Fuentes and Ventura (2000) and López-García et al. (2010b). These chorotypes are detailed as follows (Table 2): chorotype 1: includes species with mid-European requirements, with mean summer temperatures lower than $20^{\circ} \mathrm{C}$, mean annual temperatures (MAT) between 10 and $12^{\circ} \mathrm{C}$ and mean annual precipitation (MAP) higher than $800 \mathrm{~mm}$; chorotype 2: includes mid-European species tolerant of Mediterranean conditions, with a broader distribution in Catalonia than those of chorotype 1, with MAP higher than $600 \mathrm{~mm}$; chorotype 
Table 2. Representation of the number of identified specimens (NISP), the minimum number of individuals (MNI) and the percentage of the MNI (\%) for the small vertebrates from Canyars, and the small-vertebrate distribution by habitat and by chorotype. OD, open dry; OH, open humid; Wo, woodland/woodland-edge; Ro, rocky; Wa, water; Ch1, chorotype 1; Ch2, chorotype 2; Ch3, chorotype 3; (g), generalist; (m), Mediterranean requirements; indet., indeterminate. $\mathrm{x}$ represents the relationship between chorotypes and taxa.

\begin{tabular}{|c|c|c|c|c|c|c|c|c|c|c|c|}
\hline & NISP & MNI & $\%$ & OD & $\mathrm{OH}$ & Wo & Ro & Wa & Ch1 & Ch2 & Ch3 \\
\hline Pelodytes punctatus & 24 & 4 & 15.38 & 0.5 & & 0.2 & 0.1 & 0.2 & & & $\mathrm{x}(\mathrm{g})$ \\
\hline Bufo cf. bufo & 3 & 1 & 3.85 & 0.1 & 0.3 & 0.4 & & 0.2 & & & $x(g)$ \\
\hline Bufo calamita & 97 & 5 & 19.23 & 0.75 & & 0.25 & & & & & $x(g)$ \\
\hline Lacertidae indet. & 6 & 2 & 7.69 & & & & & & & & \\
\hline Anguis fragilis & 5 & 1 & 3.85 & & 0.25 & 0.75 & & & & $\mathrm{x}$ & \\
\hline Coronella cf. austriaca & 6 & 1 & 3.85 & 0.25 & 0.25 & 0.25 & 0.25 & & & $\mathrm{x}$ & \\
\hline Vipera sp. & 8 & 1 & 3.85 & 0.25 & 0.25 & 0.25 & 0.25 & & & & $\mathrm{x}(\mathrm{m})$ \\
\hline Ophidia indet. & 12 & - & & & & & & & & & \\
\hline Talpa europaea & 1 & 1 & 3.85 & & 0.5 & 0.5 & & & & $\mathrm{x}$ & \\
\hline Crocidura sp. & 1 & 1 & 3.85 & 0.5 & & 0.5 & & & & & $\mathrm{x}(\mathrm{m})$ \\
\hline Microtus arvalis & 3 & 2 & 7.69 & 0.5 & & 0.5 & & & $\mathrm{x}$ & & \\
\hline Microtus agrestis & 2 & 1 & 3.85 & & 0.5 & 0.5 & & & & $\mathrm{x}$ & \\
\hline M. (Terricola) duodecimcostatus & 2 & 1 & 3.85 & & 0.5 & 0.5 & & & & & $\mathrm{x}(\mathrm{m})$ \\
\hline M. (Iberomys) cabrerae & 1 & 1 & 3.85 & & 0.5 & 0.5 & & & & & $\mathrm{x}(\mathrm{m})$ \\
\hline Apodemus sylvaticus & 9 & 3 & 11.54 & & & 1 & & & & & $\mathrm{x}(\mathrm{g})$ \\
\hline Eliomys quercinus & 2 & 1 & 3.85 & & & 0.5 & 0.5 & & & & $\mathrm{x}(\mathrm{g})$ \\
\hline Total & 182 & 26 & 100 & & & & & & & & \\
\hline
\end{tabular}

3: includes non-strictly Mediterranean species and strictly Mediterranean species, with a broad distribution in Catalonia and without very strict requirements.

\subsection{Palaeoclimatic reconstruction}

Climatically, the Iberian Peninsula may be considered a minicontinent due to its large latitudinal range (between the parallels of $36^{\circ}$ and $44^{\circ} \mathrm{N}$ ), its geographical position between Atlantic (temperate-cold) and African-Mediterranean (temperate-warm or subtropical) influences, and its complex orography. The Iberian Peninsula is one of the most mountainous areas in Europe, and these mountains play a major role in the characterization of its climatic diversity. Climatic conditions may change abruptly over a few hundred kilometres, from the mildness of the seashore to the harshness of coastal mountain summits, resulting in a great variety of climates (Font-Tullot, 2000). The Iberian Peninsula is a restricted area with a wide variety of species, many endemic species and with many species linked to a variety of climatic requirements (Palomo and Gisbert, 2005). As a result, taxonomic composition of the assemblage allows us to evaluate the climatic conditions. In order to assess palaeoclimatic data in Canyars, we evaluated the current distribution of all the taxa found there, permitting us to calculate the potential palaeoclimatic conditions at the site (mutual climatic range method, MCR, in accordance with Blain et al., 2009; LópezGarcía et al., 2010). The method consists of ascertaining the current distribution area of the faunal association under study. This is done by superimposing the maps from atlases of current distribution, divided into $10 \mathrm{~km} \times 10 \mathrm{~km}$ UTM (Universal Transverse Mercator) squares (Palombo and Gisbert, 2005; Pleguezuelos et al., 2004). The resulting intersection will indicate an area with climate conditions similar to those of the association under study. Careful attention is paid to ensure that the real current distribution of each species corresponds to its potential ecological/climatic distribution and has not been strongly affected by other limiting or perturbing parameters such as urban development, the human impact on the landscape, predation, or competition with other species, etc. Several climatic factors are estimated based on this intersection: the mean annual temperature, the mean temperature of the coldest month (MTC), the mean temperature of the warmest month (MTW), the mean annual precipitation, the mean precipitation for summer (June, July and August, JJA) and the mean precipitation for winter (December, January and February, DJF), using various climatic maps of Spain (Font-Tullot, 2000) and data provided by the network of Catalonian meteorological research stations over a period of $30 \mathrm{yr}$. We can estimate the climatic parameters and compare them with the weather station at Barcelona Airport located about $15 \mathrm{~km}$ north of the site (current data from Font-Tullot, 2000). Barcelona Airport has a MAT of $15.6^{\circ} \mathrm{C}$ (weather station at $6 \mathrm{~m}$ a.s.l.); the mean annual precipitation is $659 \mathrm{~mm}$; the mean temperature of the coldest month is $8.8^{\circ} \mathrm{C}$; and the mean temperature of the warmest month is $23{ }^{\circ} \mathrm{C}$ (Font-Tullot, 2000). 


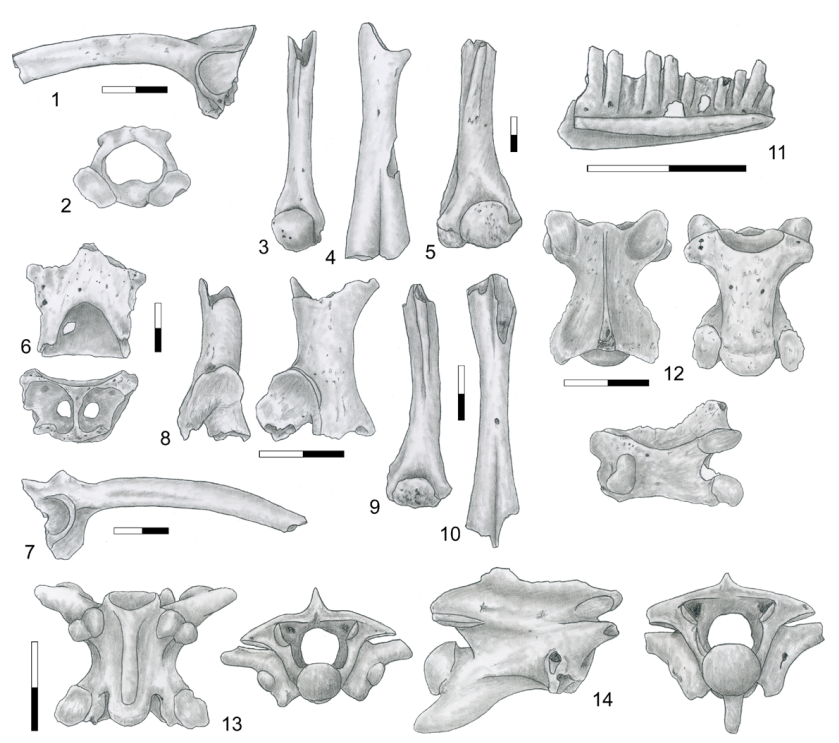

Fig. 4. Some amphibians and squamates from Canyars. 1-4, Pelodytes punctatus. 1: left ilium, lateral view; 2: atlas, anterior view; 3: right humerus of female, ventral view; 4: radioulna, lateral view; 5, Bubo cf. bufo, left humerus of female, ventral view; 6-10, Bufo calamita. 6: sphenethmoid, dorsal and anterior views; 7: right ilium, lateral view; 8: right scapula, posterior and dorsal views; 9: right humerus of female, ventral view; 10: tibiofibula, dorsal view; 11, Lacertidae indet., left dentary, medial view; 12, Anguis fragilis, trunk vertebra, dorsal, ventral and left lateral views; 13, Coronella cf. austriaca, trunk vertebra, ventral and posterior views; 14 , Vipera sp., trunk vertebra, right lateral and posterior views. All scales equal $2 \mathrm{~mm}$.

\section{Results}

\subsection{Small-vertebrate taphonomic remarks}

A total of 362 elements from Canyars have been studied in our taphonomic analysis; $57 \%$ of the remains are from rodents or insectivores, and the remaining $43 \%$ belong to amphibians and reptiles. The taphonomic study of the microvertebrate fossils is based on a descriptive-systematic method that analyses the modifications produced by predation (Andrews, 1990). The surface alterations present on the microvertebrate remains are thus noted and described, making it possible to identify and recognize the effects of predators. To this end, the anatomical representation, the fragmentation and the digestion marks on the remains are analysed, and the results are compared with those obtained by studying modern pellets from well-known predators.

Alterations caused by digestion were found in most of the small mammals (Fig. 5) and in $3.2 \%$ of the amphibians and reptiles (P. punctatus, B. calamita and A. fragilis). The high percentage of small-mammal incisors, molars and postcranial elements showing digestion marks (Fig. 5) and the degree of alteration point to the presence of a category 3 predator, which includes several avian predators (Andrews,

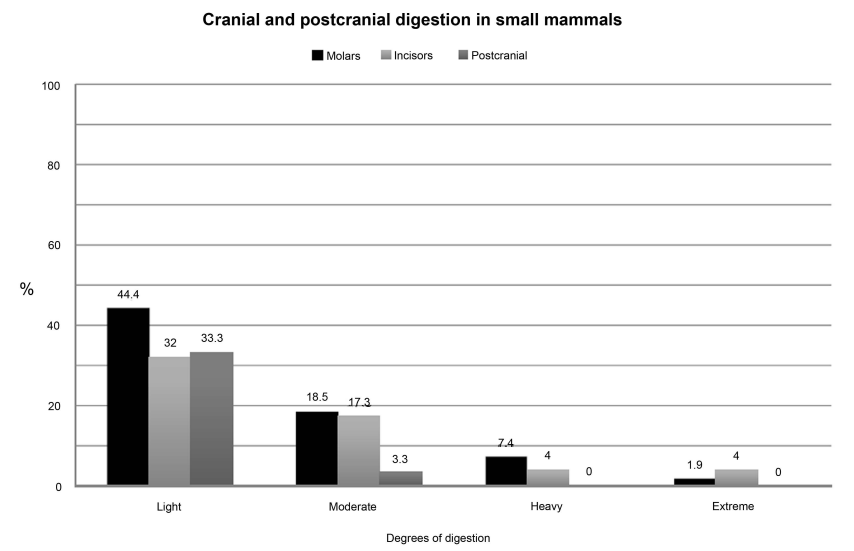

Fig. 5. Percentages of small-mammal elements from Canyars showing different degrees of digestion. We identify 4 degrees of digestion, from light to extreme, following the method of Andrews (1990) for incisors and molars, and the method of FernándezJalvo (1992) for postcranial elements. There are some elements that could not be classified to their degree of digestion, because they were not digested. There are the $27.8 \%$ of molars, the $42.7 \%$ of incisors and the $63.4 \%$ of postcranial elements.

1990), such as Falco tinnunculus. This indicates that the accumulation is associated with predation, although in the case of the amphibians, in particular $P$. punctatus and above all B. calamita, in situ mortality cannot be ruled out given the NISP/MNI ratio, which is considerably higher than in the other anurans and the reptiles.

The common kestrel (F. tinnunculus) is a diurnal bird of prey with a moderately selective diet, which is generally based on small mammals (by choice mice, microtines and shrews), although it also consumes passeriform birds, insects, reptiles and amphibians (Andrews, 1990; Gil-Delgado et al., 1995). Predation on A. fragilis, certain lacertids and vipers by $F$. tinnunculus has been well documented (Elósegui, 1973; Braña, 1984; Salvador, 1997). Although there is no recorded predation of $C$. austriaca by $F$. tinnunculus, it is well established that it may form the prey of certain diurnal birds (Salvador, 1997). As for anurans, the fact that they are largely nocturnal in habit (except during the reproductive season) makes them infrequent prey for diurnal raptors (García-París et al., 2004), although the predation of Falco naumanni on P. punctatus has been documented (Martín and López, 1990). As for its habitat, F. tinnunculus can be found on cliffs, steppe land, scrubland and open, sparse woodland. In general, it avoids densely forested areas and requires open spaces for hunting.

The above considerations lead us to infer on the one hand that the taxa identified in this study might reflect the existent past community of microvertebrates, though this should be taken with caution given the diurnal and moderately selective habits of $F$. tinnunculus. On the other hand, the probable accumulation of small mammals by F. tinnunculus suggests 
Table 3. Percentage representations of alterations caused by postdepositional agents in Canyars microvertebrates.

\begin{tabular}{lr}
\hline \multicolumn{2}{c}{$\begin{array}{c}\text { Alterations caused by } \\
\text { postdepositional agents }\end{array}$} \\
\hline Manganese oxide & 54 \\
Root grooves & 10.3 \\
Abrasion & 5.3 \\
Chemical corrosion & 4 \\
Fissures & 2.5 \\
Concretions & 0.7 \\
Calcium carbonate & 0.7 \\
Weathering & 0.3 \\
\hline
\end{tabular}

that open or semi-open palaeoecological conditions prevailed in the area around Canyars.

As for postdepositional alterations, Canyars exhibits a predominance of light manganese oxide precipitations and alterations caused by roots (Table 3 ), thus would indicate a predominantly humid fossilization microenvironment. Furthermore, marks caused by trampling on small-mammal bone surfaces have been recorded, suggesting a postdeposicional sediment abrasion. Alterations caused by weathering, as well as other forms of alteration associated with changes in humidity and desiccation (fissures and concretions) are present in low percentages.

\subsection{Small-vertebrate assemblage from Canyars}

The small vertebrates of Canyars comprise at least 15 species (Table 2; Figs. 3, 4): 3 amphibians (Pelodytes punctatus, Bufo cf. bufo and Bufo calamita); 4 squamates (Lacertidae indet., Anguis fragilis, Coronella cf. austriaca and Vipera sp.); 2 insectivores (Talpa europaea and Crocidura sp.); and 6 rodents (Microtus arvalis, M. agrestis, M. (Terricola) duodecimcostatus, M. (Iberomys) cabrerae, Apodemus sylvaticus and Eliomys quercinus).

The small-mammal assemblage at Canyars is characterized by the abundance of Apodemus sylvaticus and Microtus arvalis. Mediterranean taxa, such as Microtus (Iberomys) cabrerae and Microtus (Terricola) duodecimcostatus, and mid-European taxa, such as Microtus arvalis, Microtus agrestis and Talpa europaea, are equally well represented. From a quantitative point of view, the wood mouse (Apodemus sylvaticus) and the common vole (Microtus arvalis) are highly represented at Canyars, often accounting for more than $40 \%$ of the total sample. Among the fossil material analysed here, A. sylvaticus corresponds to $27.3 \%$ and $M$. arvalis corresponds to $18.2 \%$ of the total sample. The presence of $A$. sylvaticus at late Pleistocene sites is common, but such abundance is rare in late Pleistocene cave localities (see for example Sesé, 1994, 2005; Pokines, 1998; CuencaBescós et al., 2008, 2009; and López-García, 2008; LópezGarcía et al., 2011b, 2012a, b), because during these gener- ally cold periods the dominant species, such as $M$. arvalis or $M$. agrestis, are normally associated with open environments, replacing A. sylvaticus. Today, however, A. sylvaticus is a very abundant species throughout Spain. It is a generalist species, but its greatest abundance is currently reported to be in the woodland-edge/woodland habitats (Palomo and Gisbert, 2005). On the other hand, the abundance of $M$. arvalis is relatively common in late Pleistocene cave localities (Pokines, 1998; Sesé, 1994, 2005; Cuenca-Bescós et al., 2008, 2009; López-García, 2008; López-García et al., 2010a, 2011a), and today it is a very abundant species in central and northern Spain. M. arvalis is currently reported to be more frequent in open lands, and common in relatively dry regions of Spain (Palomo and Gisbert, 2005).

However, apart from Crocidura sp., M. (Terricola) duodecimcostatus, Apodemus sylvaticus and Eliomys quercinus, none of the taxa represented at Canyars is currently found in the vicinity of the site. Nowadays, 13 smallmammal species live on this part of the Catalonian coast, among them insectivores and rodents (Vigo, 2002). Including the species introduced in historical times (such as Atelerix, Suncus, Rattus and Mus), the Canyars small-mammal assemblage represents $61.5 \%$ of the current small-mammal fauna of the Catalan coast in terms of species number.

As far as amphibians and squamates are concerned, the fossils from Canyars only document $30.4 \%$ of the current diversity of the Garraf area: $37.5 \%$ of the anurans and $26.7 \%$ of the squamates (modern data from Montori, 1996; Llorente et al., 1995; Rivera et al., 2011). As said above, the representation of the current herpetofauna may be because the accumulation could be produced by a diurnal bird of category 3 ( $F$. tinnunculus), but natural death is not excluded in some cases for $P$. punctatus and B. calamita. All the taxa represented as fossils in the locality, except $C$. austriaca and Vipera, are well represented today in the Garraf area (Montori, 1996). The scarcity of Vipera today may be linked with the increasing urbanization of the landscape, whereas $C$. austriaca is currently absent from the Catalan seashore following a postglacial regression (Llorente et al., 1995; Rivera et al., 2011). It is interesting to note here that $C$. austriaca is found today in Catalonian mountain regions (Eurosiberian habitats or humid mountain areas; Rivera et al., 2011), where MAT is lower than $11^{\circ} \mathrm{C}$ and MAP higher than 700-800 mm (Llorente et al., 1995). Although mention of the genus Coronella is not rare in the Catalonian Pleistocene fossil record, C. austriaca has only been cited in the southern part of its current distribution in the late Pleistocene (ca. 90-30 Ka) of Teixoneres cave (Moià, Barcelona; López-García et al., 2012b).

\subsection{Palaeoenvironmental and Palaeoclimatic reconstruction}

The resulting intersection for Canyars suggests a mean annual temperature lower than at present $\left(-5.2^{\circ} \mathrm{C}\right)$ and a 
A

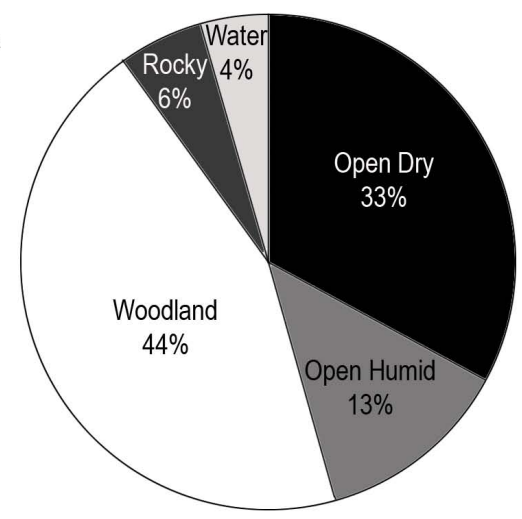

B

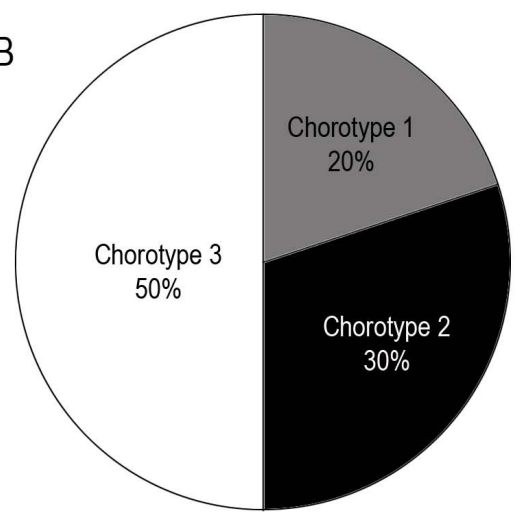

Fig. 6. (A): small-vertebrate association by habitat. (B): smallvertebrate association by chorotype. Data have been taken from the percentage of the minimum number of individuals.

mean annual precipitation slightly higher than at present $(+99 \mathrm{~mm})$. The mean temperature of the coldest month is lower than the current mean $\left(-6.1^{\circ} \mathrm{C}\right)$, and for the warmest month it is also lower $\left(-4.5^{\circ} \mathrm{C}\right)$. The mean winter precipitation (DJF) is higher $(+55 \mathrm{~mm})$, and the mean summer precipitation (JJA) is lower $(-29 \mathrm{~mm})$ than at present (Table 4$)$. These data suggest lower temperatures and slightly higher precipitation than at present for the $\mathrm{H} 4$ event in northeastern Iberia. Such data are well supported by the presence of taxa such as $C$. austriaca at Canyars, which, as pointed out above, currently lives in mountain areas where MAT is lower than $11^{\circ} \mathrm{C}$ and MAP higher than $700-800 \mathrm{~mm}$ (Llorente et al., 1995).

Otherwise, the small-vertebrate assemblage for Canyars indicates an open dry environment (33\%) (Fig. 6), given the presence of the species Pelodytes punctatus, Bufo calamita, Vipera sp., Crocidura sp. and Microtus arvalis. It further suggests a landscape alternating between dry meadowland and Mediterranean-type woodland. The species associated with "woodland" habitats represent $44 \%$ of the total association (Fig. 6), mainly composed of B. cf. bufo, Anguis fragilis, Apodemus sylvaticus and Eliomys quercinus. There is also a low percentage representation of species associated
Table 4. Relation of temperature and precipitation for Canyars. MAT, mean annual temperatures; MTC, mean temperature of coldest month; MTW, ,mean temperature of warmest month; MAP, mean annual precipitation; DJF, mean winter precipitation; JJA, mean summer precipitation; $n$, number of intersection points; Max, maximum of values obtained; Min, minimum of values obtained; Mean, mean of values obtained; SD, standard deviation of values obtained. Current values have been obtained from the Barcelona Airport meteorological station (data from Font-Tullot, 2000).

\begin{tabular}{lrrrrrr}
\hline & $n$ & mean & Max & Min & sd & $\begin{array}{r}\text { Current } \\
\text { Values }\end{array}$ \\
\hline MAT & 46 & 10.11 & 13.00 & 6.00 & 1.75 & 15.6 \\
MTC & 46 & 2.72 & 9.00 & 0.00 & 1.59 & 8.8 \\
MTW & 46 & 18.50 & 22.00 & 16.00 & 1.35 & 23 \\
MAP & 46 & 757.6 & 1200 & 450 & 177 & 659 \\
DJF & 46 & 175.2 & 256 & 95 & 40 & 129 \\
JJA & 46 & 96.96 & 197 & 71 & 37 & 138 \\
\hline
\end{tabular}

with open humid meadows (13\%) and water streams (4\%) (Fig. 6), suggesting the existence of stable watercourses in the vicinity of the site, with riverbanks with loose soils favourable for digging species such as A. fragilis, Bufo cf. bufo, $C$. cf. austriaca and Talpa europaea.

Finally, the small-vertebrate assemblage of the Canyars site indicates an equitable representation of taxa related with mid-European requirements (chorotype 1 and 2, $50 \%$ ), and taxa related with Mediterranean requirements (chorotype $3,50 \%$; Fig. 6). According to Sommer and Nadachowski (2006), the co-occurrence of temperate and coldadapted species is the normal dynamic detected in southern European peninsulas such as the Iberian Peninsula, which functioned as refuges for species in cold periods, in this case during the H4 event. However, in Cova del Gegant (LópezGarcía et al., 2008, 2012c), another late Pleistocene locality of the Garraf Massif, chronologically placed between 49$60 \mathrm{Ka}$ (i.e. before HE4), Mediterranean taxa are dominant (chorotype 3,89\%) showing a different climatic signal in small vertebrates assemblage. Moreover the proximity of the Canyars to the coastline meant that in cold periods, when the sea level decreased, there was a coastal plain with probably drier conditions in front of the site and behind a forested area with more humid conditions offering rocky and woodland habitats.

Other terrestrial proxies such as charcoal, pollen, phytoliths, avifauna and large mammals from the Canyars site have also been analysed (Daura et al., 2013). The pollen (Artemisia), avifauna (Pyrrhocorax graculus) and largemammal (cf. Mammuthus sp., Coelodonta antiquitatis and Equus ferus) results indicate the presence of a steppedominant landscape surrounding the Canyars site. The woodland landscape is indicated by forest taxa, such as Pinus sylvestris, deciduous Quercus and Acer, and by temperate forest large mammals, such as Sus scrofa, Lynx pardinus and 


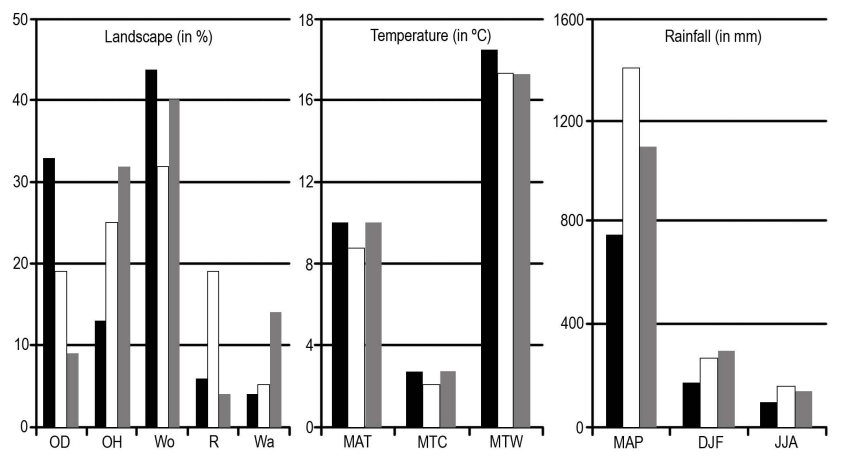

Fig. 7. Environmental and climatic comparisons between Canyars (black bar), El Portalón (white bar) and Cueva del Conde (grey bar). Data for El Portalón are from López-García et al. (2010a) and for Cueva del Conde are from López-García et al. (2011b). Abbreviations: OD, open dry; OH, open humid; Wo, woodland; R, rocky; Wa, water edge; MAT, mean annual temperature; MTC, mean temperature of the coldest month (January); MTW, mean temperature of the warmest month (July); MAP, mean annual precipitation; DJF, mean winter precipitation; and JJA, mean summer precipitation.

Ursus arctos. The charcoal results indicate a dominance of forest (Pinus sylvestris) formations, while the phytoliths indicate a dominance of grasslands, representing arid conditions (Daura et al., 2013).

\section{Comparison and discussion}

\subsection{Comparison with other sites associated with the $\mathrm{H} 4$ event}

Few are the sites with small-vertebrate studies in Iberia where the $\mathrm{H} 4$ event has been detected, and Canyars is the only known site located on the Mediterranean and below $41^{\circ} \mathrm{N}$ latitude. Apart from Canyars, two sites are documented with small-vertebrate assemblages from the $\mathrm{H} 4$ event: El Portalón level P16 (Sierra de Atapuerca, Burgos), with a chronology of ca. $38 \mathrm{Ka}$ for this event; and the Cueva del Conde level N20b (Santo Adriano, Asturias), with a chronology of ca. $39 \mathrm{Ka}$ for this event (Fig. 1; López-García et al., 2010a, 2011b). All the sites associated with the H4 event are characterized by a landscape dominated by open forest formations, lower mean annual temperatures and mean temperatures of the coldest month, and relatively high levels of mean annual precipitation (Fig. 7). However, direct comparison of these three sites shows differences between them in terms of open dry and open humid meadowland and MAP. While in El Portalón (P16) and Cueva del Conde (N20b) the environment is dominated by open humid meadowland reaching values higher than $25 \%$, in Canyars the landscape is dominated by open dry meadowland with values above $30 \%$ (Fig. 6). Similarly, the MAP, although higher than at present in all three cases, is proportionally higher at El Portalón (P16) and Cueva del Conde (N20b), where it

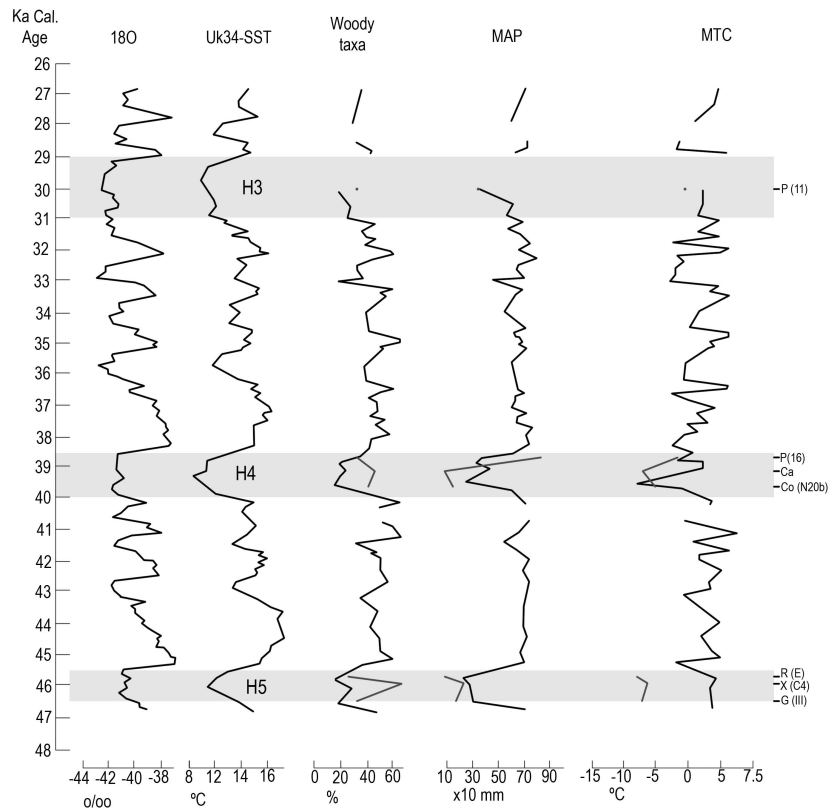

Fig. 8. Proposed correlation of the North GRIP2 isotope $\left({ }^{18} \mathrm{O}\right)$ curve, the quantitative variation in the annual sea surface temperature (Uk37-SST), the synthetic pollen diagram from the last glacial section (47-27 cal Ka) of core MD95-2043, and the values estimated for annual precipitation and mean temperature of the coldest month in southeastern Iberia (modified from Sánchez-Goñi et al., 2002) with the various layers with small-vertebrate studies where H3 to H5 events have been detected. P (11 and 16): El Portalón layer P11 and P16; Ca: Terrassa Riera dels Canyars (Canyars); Co (N20b): Cueva del Conde layer N20b; R (E): Abric Romaní layer E; and G (III): Cova del Gegant layer III (grey lines indicate the data obtained with these studies).

reaches values higher than $1000 \mathrm{~mm}$, while in Canyars the values are lower than $800 \mathrm{~mm}$ (Fig. 7). The differences in the $\mathrm{H} 4$ event at these three sites can be explained by their geographical position within the Iberian Peninsula: while El Portalón and Cueva del Conde are located in the Atlantic climatic influence, Canyars is located in the Mediterranean climatic influence. According to Sánchez-Goñi et al. (2002) and Sepulchre et al. (2007), the Atlantic sea core (MD95-2042) shows a MAP of about $300 \mathrm{~mm}$ higher than the Mediterranean sea core (MD95-2043) during the $\mathrm{H} 4$ event, providing the Iberian Atlantic region with more humid environmental conditions than in the Mediterranean region today, as is also shown by the results obtained from the small-vertebrate studies. However, the different vegetation phases detected by Fletcher and Sánchez-Goñi (2008), have not been clearly individualized with our data. Probably the El Portalón (P16) and Cueva del Conde (N20b) small-vertebrate detected fluctuations could be related, according to Fletcher and SánchezGoñi (2008), with the early phase of the H4 event, with generally cold but humid conditions. On the other hand, Canyars with high values in Artemisia, and drier conditions than the 
Table 5. Relation between woodland percentage, mean annual precipitation and mean temperature of coldest month for the different sites where the $\mathrm{H} 3$ to $\mathrm{H} 5$ events have been detected.

\begin{tabular}{rrlrrr}
\hline HE & Ka & Sites & Woodland $(\%)$ & MAP $(\mathrm{mm})$ & MTC $\left({ }^{\circ} \mathrm{C}\right)$ \\
\hline 3 & ca. 30 & Portalón (P11) & 34 & 378 & -0.1 \\
\hline & ca. 38 & Portalón (P16) & 32 & 841 & -0.6 \\
4 & ca. $38-39$ & Canyars & 44 & 98.6 & -6.08 \\
& ca. 39-40 & Conde (N20b) & 40 & 127 & -5 \\
\hline & ca. 46 & A. Romaní (E) & 25 & 90 & -6.41 \\
5 & ca. 45-48 & Xaragalls (C4) & 66 & 266 & -6.05 \\
& ca. 49 & Gegant (III) & 48 & 191 & -6.2 \\
\hline
\end{tabular}

other two sites could be related with the main phase of the H4 event.

\subsection{Discussion}

In general, the studies of the sea cores (MD95-2042, MD952043 and MD99-2343) from the Iberian margins show the Heinrich events, including the $\mathrm{H} 4$ event, to have been characterized by low sea surface temperatures (SST), with values of -7 to $-10^{\circ} \mathrm{C}$, and a climate on land drier than today, with lower levels of Mediterranean forest and higher levels of steppe vegetation (Cacho at al., 1999; Sánchez-Goñi et al., 2002; Sánchez-Goñi and d'Errico, 2005; Sierro et al., 2005; Sepulchre et al., 2007). Despite these general data, there are differences between the Heinrich events and within them. The H4 event and the previous (H5) and subsequent events (H3) are characterized by a fluctuation in woodland taxa and in the extrapolated mean temperatures of the coldest month and mean annual precipitation (Sánchez-Goñi et al., 2002; Naughton et al., 2009; Fig. 8). According to these data, the $\mathrm{H} 4$ event is considered the most abrupt event compared with the $\mathrm{H} 3$ and $\mathrm{H} 5$ events, with the MTC between -6 and $-10^{\circ} \mathrm{C}$ compared to nowadays and the MAP $400 \mathrm{~mm}$ lower than at present in the Iberian Mediterranean region and $200 \mathrm{~mm}$ lower than currently in the Iberian Atlantic region (Sánchez-Goñi et al., 2002; Naughton et al., 2009). According to Cacho et al. (1999) and Sierro et al. (2005), the $\mathrm{H} 3$ event is the least cold in comparison to the $\mathrm{H} 4$ and $\mathrm{H} 5$ events. The data obtained with small-vertebrate studies for the H4 event and the H3 and H5 events (López-García et al., 2010a, 2011b, 2012a, c; López-García and Cuenca-Bescós, 2010) seem to follow the same patterns previously established by the sea core studies at the Iberian margins (Table 5; Fig. 8). The small-vertebrate studies show that fluctuations in the percentage values for woodland taxa follow the same pattern as the woody taxa established for the sea core MD95-2043, reaching minimum values (25\%) in H5 event layer E from the Abric Romaní (López-García and CuencaBescós, 2010; Burjachs et al., 2012) (Table 5; Fig. 8). As with the woodland percentage representations, the MTC and the MAP established by means of small-vertebrate studies for the $\mathrm{H} 5$ to $\mathrm{H} 3$ events follow the same pattern as the curves extrapolated from the sea core MD95-2043 (Sánchez-Goñi et al., 2002) (Table 5; Fig. 8), reaching minimum values in $\mathrm{H} 5$ event layer $\mathrm{E}$ from the Abric Romani $\left(\mathrm{MTC}=-6.41^{\circ} \mathrm{C}\right.$; $\mathrm{MAP}=+90 \mathrm{~mm}$, in relation to the present) (López-García and Cuenca-Bescós, 2010) and in the $\mathrm{H} 4$ event from Canyars $\left(\mathrm{MTC}=-6.08^{\circ} \mathrm{C} ; \mathrm{MAP}=+99 \mathrm{~mm}\right.$, in relation to the present) (Table 5; Fig. 8). Although, the different phases detected with vegetation data (Fletcher and Sánchez-Goñi, 2008) have been not clearly individualized with our data. Moreover, direct comparison between level III of Cova del Gegant and the Canyars site reveals less rigorous conditions for the H5 event at the former, where there is no representation of the mid-European species M. agrestis, T. europaea, A. fragilis and C. austriaca, which do appear at Canyars (López-García et al., 2012c). As has previously been pointed out by Cacho et al. (1999) and Sierro et al. (2005), however, small-vertebrate studies show the $\mathrm{H} 3$ event to be the least harsh of these Heinrich events, with values for $\mathrm{MAP}=+378 \mathrm{~mm}$ and $\mathrm{MTC}=-0.1{ }^{\circ} \mathrm{C}$ with respect to the present for layer P11 of El Portalón (López-García et al., 2010a) (Table 5; Fig. 8).

\section{Conclusions}

The data derived from the studied small vertebrates recovered from Canyars add further to our knowledge of the H4 event in the Iberian Peninsula. The small-vertebrate assemblage reveals that the $\mathrm{H} 4$ event was characterized in northeastern Iberia by cold climatic conditions, with a landscape alternating between dry meadowland and Mediterraneantype woodland. This assemblage is composed by an equitable representation of mid-European taxa together with Mediterranean taxa, a co-occurrence that is the normal dynamic detected in southern European peninsulas, which functioned as refuge for species in cold periods. The location of Canyars may have also provided a coastal plain in front of the site with drier conditions and a Mediterranean forest behind with more humid conditions than today. 
Secondly, a direct comparison of the data obtained from the small-vertebrate association from Canyars with other terrestrial proxies that have been studied, such as charcoal, pollen, phytoliths, birds and large mammals, corroborates our data, showing that the climate during the $\mathrm{H} 4$ event was harsher and drier than today in the northeastern Iberian Peninsula.

Furthermore, a comparison with the other small-vertebrate studies in the Iberian Peninsula where the $\mathrm{H} 4$ event has been detected, such as El Portalon layer P16 or Cueva del Conde layer N20b, shows this event to be characterized by a landscape dominated by open forest formations, with lower mean annual temperatures (MAT) and mean temperatures of the coldest month (MTC), and relatively high levels of mean annual precipitation (MAP). However, the H4 event provided the Iberian Atlantic region (El Portalón and Cueva del Conde) with more humid environmental conditions than the Mediterranean region (Canyars), as is also shown by the previous results obtained by sea core samples from the Iberian margins.

Finally, a comparison of our data obtained from the smallvertebrate assemblage with the general dynamic of the Heinrich events reveals that the small-vertebrate studies for the $\mathrm{H} 3$ to H5 events in the Iberian Peninsula follow the same pattern as the previous studies undertaken for the Iberian margin sea cores, showing that the $\mathrm{H} 4$ event is the most abrupt event compared with the $\mathrm{H} 3$ and $\mathrm{H} 5$ events and that $\mathrm{H} 3$ is the least cold of the three.

Acknowledgements. This paper is a product of the research project Els Primers Pobladors de Garraf-Ordal, supported by SGR2009-1145, 2008ACOM00016, HAR2011-26193 and the projects CGL2012-38358 and SGR2009-324. Fieldwork was sponsored by GTI (Gavanenca de Terrenys i Inmobles, Ajuntament de Gavà). J. M. López-García is a beneficiary of a Beatriu de Pinós postdoctoral fellowship (2011BP-A00272) from the Generalitat de Catalunya, a grant co-funded by the European Union through the Marie Curie Actions of the 7th Framework Program for R+D. J. Daura was supported by a postdoctoral grant (Juan de la Cierva Subprogram), M. Sanz by a predoctoral grant (FI) from the Comissionat per a Universitats i Recerca del Departament d'Innovació, Universitats i Empresa de la Generalitat de Catalunya and the Fons Social Europeu.

Edited by: M. Fuchs

\section{References}

Andrews, P.: Owls, caves and fossils. Predation, preservation and accumulation of small mammal bones in caves, with an analysis of the Pleistocene cave faunas from Westbury-sub-Mendip, Somerset, UK, Natural History Museum Publications, London, 231 pp., 1990.

Andrews, P.: Taphonomic effects of faunal impoverishment and faunal mixing, Palaeogeogr. Palaeocl., 241, 572-589, 2006.
Bailon, S.: Différenciation ostéologique des Anoures (Amphibia, Anura) de France, in: Fiches d'ostéologie animale pour l'archéologie, Série C: varia, edited by: Desse, J. and DesseBerset, N., Centre de Recherches Archéologiques - CNRS, Valbonne, 1999.

Blain, H.-A.: Contribution de la paléoherpétofaune (Amphibia \& Squamata) à la connaissance de l'évolution du climat et du paysage du Pliocène supérieur au Pléistocène moyen d'Espagne, Ph.D. dissertation. Muséum National d'Histoire Naturelle de Paris. Département de Préhistoire, Institut de Paléontologie humaine, 2005.

Blain, H.-A.: Contribution de la paléoherpétofaune (Amphibia \& Squamata) à la connaissance de l'évolution du climat et du paysage du Pliocène supérieur au Pléistocène moyen d'Espagne, Treballs de Museu de Geologia de Barcelona, 16, 39-170, 2009.

Blain, H.-A., Bailon, S., and Cuenca-Bescós, G.: The Early-Middle Pleistocene palaeoenvironmental change based on the squamate reptile and amphibian proxy at the Gran Dolina site, Atapuerca, Spain, Palaeogeogr. Palaeocl., 261, 177-192, 2008.

Blain, H.-A., Bailon, S., Cuenca-Bescós, G., Arsuaga, J. L., Bermúdez de Castro, J. M., and Carbonell, E.: Long-term climate record inferred from early-middle Pleistocene amphibian and squamate reptile assemblages at the Gran Dolina Cave, Atapuerca, Spain, J. Hum. Evol., 56, 55-65, 2009.

Bout-Roumazeille, V., Combourieau Nebout, N., Peyron, P., Cortijo, E., Landais, A., and Masson-Delmotte, V: Connection between South Mediterranean climate and North African atmospheric circulation during the last 50,000 yr BP North Atlantic cold events, Quaternary Sci. Rev., 26, 3197-3215, 2007.

Braña, F.: Biogeografía, biología y estructura de nichos de la taxocenosis de saurios de Asturias. Ph.D. Thesis, Universidad de Oviedo, Oviedo, 436 pp., 1984.

Bronk Ramsey, C.: Radiocarbon calibration and analysis of stratigraphy: the OxCal program, Radiocarbon, 37, 425-430, 1995.

Burjachs, F., López-García, J. M., Allué, E., Blain, H.-A., Rivals, F., Bennàsar, M., and Expósito, I.: Palaeoecology of Neanderthals during Dansgaard-Oeschger cycles in northeastern Iberia (Abric Romaní): From regional to global scale, Quaternary Int., 247, 26-37, 2012.

Cacho, I., Grimalt, J. O., Pelejero, C., Canals, M., Sierro, F. J., Flores, J. A., and Shackleton, N.: Dansgaard-Oeschger and Heinrich event imprints in Alboran Sea paleotemperatures, Paleocenography, 14, 698-705, 1999.

Cayre, O., Lancelot, Y., Vincent, E. M., and Hall, M. A.: Paleoceanographic reconstructions from planktonic foraminifera off the Iberian margin: temperature, salinity and Heinrich events, Palaeoceanography, 14, 384-396, 1999.

Combourieu Nebout, N., Turon, J. L., Zahn, R., Capotondi, L., Londeix, L., and Pahnke, K.: Enhanced aridity and atmospheric high-pressure stability over the western Mediterranean during the North Atlantic cold events of the past 50 ky, Geology, 30, 863866, 2002.

Cuenca-Bescós, G., Rofes, J., and García Pimienta, J. C.: Environmental change across the Early-Middle Pleistocene transition: small mammalian evidence from the Trinchera Dolina cave, Atapuerca, Spain, in: Early-Middle Pleistocene Transitions: The Land-Ocean Evidence, edited by: Head, M. J. and Gibbard, P. L., 277-388, Geological Society of London, Special Publication 247, 2005. 
Cuenca-Bescós, G., Straus, L. G., González Morales, M., and García Pimienta, J. C.: Los pequeños mamíferos del final del Cuaternario en Cantabria: La Cueva del Mirón (Ramales de la Victoria), Revista Española de Paleontologia, 23, 91-126, 2008.

Cuenca-Bescós, G., Straus, L. G., González Morales, M., and 0García Pimienta, J. C.: The reconstruction of past environments through small mammals: from the Mousterian to Bronze Age in El Mirón cave, J. Archaeolog. Sci., 36, 947-955, 2009.

Cuenca-Bescós, G., Agustí, J., Lira, J., Melero Rubio, M., and Rofes, J.: A new species of water vole from the Early Pleistocene of Southern Europe, Acta Paleontol. Pol., 55, 565-580, 2010.

Daura, J. and Sanz, M.: Jaciments Plistocens i ocupacions humanes en el Paleolític de Gavà, L'arqueologia a Gavà. Homenatge a Alícia Estrada, Col.leció La nostra Gent, 5. Ed Associació d'Amics del Museu de Gavà i Ajuntament de Gavà, Gavà, 1-44, 2009.

Daura, J., Sanz, M., García, N., Allué, E., Vaquero, M., Fierro, E., Carrión, J. S., López-García, J. M., Blain, H.-A., SánchezMarco, A., Valls, C., Albert, R. M., Fornós, J. J., Julià, R., Fullola, J. M., and Zilhao, J.: Terrasses de la Riera dels Canyars (Barcelona, Spain): the landscape of Heinrich Event 4 north of the "Ebro frontier" and implications for modern human dispersal into Iberia, Quaternary Sci. Rev., 60, 26-48, 2013.

Elósegui, J.: Informe preliminar sobre alimentación de aves rapaces en Navarra y provincias limítrofes, Ardeola, 19, 249-256, 1973.

Evans, E. M. N., Van Couvering, J. A. H., and Andrews, P.: Palaeoecology of Miocene Sites in Western Kenya, J. Hum. Evol., 10, 99-116, 1981.

Fernández-Jalvo, Y.: Tafonomía de microvertebrados del complejo kárstico de Atapuerca (Burgos), Tesis Doctoral, Universidad Complutense de Madrid, 1992.

Fletcher, W. J. and Sánchez Goñi, M. F.: Orbital- and sub-orbitalscale climate impacts on vegetation of the western Mediterranean basin over the last 48,000 yr, Quaternary Res., 70, 451-464, 2008.

Fletcher, W. J., Sánchez-Goñi, M. F., Allen, J. R. M., Cheddadi, R., Combourieu-Nebout, N., Huntley, B., Lawson, I., Londeix, L., Magri, D., Margari, V., Müller, U. C., Naughton, F., Novenko, E., Roucoux, K., and Tzedakis, P. C.: Millennial-scale variability during the last glacial in vegetation records from Europe, Quaternary Sci. Rev., 29, 2839-2864, 2010.

Font-Tullot, I.: Climatología de España y Portugal, 422 pp., Ediciones Universidad de Salamanca, Salamanca, 2000.

Furió, M.: Los Insectívoros (Soricomorpha, Erinaceomorpha, Mammalia) del Neógeno Superior del Levante Ibérico, 299 pp., Departament de Geologia, Universitat Autónoma de Barcelona, Barcelona, 2007.

García-París, M., Montori, A., and Herrero, P.: Amphibia. Lissamphibia, in: Fauna Ibérica, Vol. 24, edited by: Ramos, M. A. et al., Museo Nacional de Ciencias Naturales, Consejo Superior de Investigaciones Científicas, Madrid, 640 pp., 2004.

Gil-Delgado, J. A., Verdejo, J., and Barba, E.: Nestling diet fledging production of Eurasian kestrel (Falco tinnunculus) in eastern Spain, J. Raptor Res., 29, 240-244, 1995.

Llorente, G. A., Montori, A., Santos, S., and Carretero, M. A.: Atlas dels Amfibis i Rèptils de Catalunya i Andorra, Edicions El Brau, Figueres, 192 pp., 1995.

López-García, J. M.: Evolución de la Diversidad Taxonómica de los Micromamíferos en la Peninsula Ibérica y Cambios Paleoam- bientales Durante el Pleistoceno Superior, 347 pp., Universitat Rovira i Virgili, Tarragona, 2008.

López-García, J. M. and Cuenca-Bescós, G.: Evolution climatique durant le Pléistocène Supérieur en Catalogne (Nord-est de l'Espagne) d'après l'étude des micromammifères, Quaternaire, 21, 249-258, 2010.

López-García, J. M., Blain, H.-A., Cuenca-Bescós, G., and Arsuaga, J. L.: Chronological, environmental and climatic precisions on the Neanderthal site of the Cova del Gegant (Sitges, Barcelona, Spain), J. Hum. Evol., 55, 1151-1155, 2008.

López-García, J. M., Blain, H.-A., Cuenca-Bescós, G., RuizZapata, M. B., Dorado-Valiño, M., Gil-García, M. J., Valdeolmillos, A., Ortega, A. I., Carretero, J. M., Arsuaga, J. L., Bermúdez de Castro, J. M., and Carbonell, E.: Palaeoenvironmental and palaeoclimatic reconstruction of the Latest Pleistocene of El Portalón Site, Sierra de Atapuerca, northwestern Spain, Palaeogeogr. Palaeocl., 292, 453-464, 2010a.

López-García, J. M., Blain, H.-A., Allué, E., Bañuls, S., Bargalló, A., Martín, P., Morales, J. I., Pedro, M., Rodriguez, A., Solé, A., and Oms, F. X.: First fossil evidence of an "interglacial refugium" in the Pyrenean region, Naturwissenschaften, 97, 753-761, 2010b.

López-García, J. M., Blain, H.-A., Cuenca-Bescós, G., Alonso, C., Alonso, S., and Vaquero, M.: Small vertebrates (Amphibia, Squamata, Mammalia) from the late Pleistocene-Holocene of the Valdavara-1 cave (Galicia, northwestern Spain), Geobios, 44, 253-269, 2011a.

López-García, J. M., Cuenca-Bescós, G., Blain, H.-A., ÁlvarezLao, D., Uzquiano, P., Adán, G., Arbizu, M., and Arsuaga, J. L.: Palaeoenvironment and palaeoclimate of the MousterianAurignacian transition in northern Iberia: The small-vertebrate assemblage from Cueva del Conde (Santo Adriano, Asturias), J. Hum. Evol., 61, 108-116, 2011 b.

López-García, J. M., Blain, H.-A., Bennàsar, M., Euba, I., Bañuls, S., Bischoff, J., López-Ortega, E., Saladié, P., Uzquiano, P., and Vallverdú, J.: A multiproxy reconstruction of the Late Pleistocene in northeastern Iberia: Cova dels Xaragalls, VimbodíPoblet, Paratge Natural de Poblet, Catalonia, Boreas, 41, 235249, 2012a.

López-García, J. M., Blain, H.-A., Burjachs, F., Ballesteros, A., Allué, E., Cuevas-Ruiz, G. E., Rivals, F., Blasco, R., Morales, J. I., Rodriguez Hidalgo, A., Carbonell, E., Serrat., D., and Rosell, J.: A multidisciplinary approach to reconstructing the chronology and environment of southwestern European Neanderthals: the contribution of Teixoneres cave (Moià, Barcelona, Spain), Quaternary Sci. Rev., 43, 33-44, 2012b.

López-García, J. M., Blain, H.-A., Sanz, M., and Daura, J.: A coastal reservoir of terrestrial resources for Neanderthal populations in north-eastern Iberia: palaeoenvironmental data inferred from the small-vertebrate assemblage of Cova del Gegant, Sitges, Barcelona, J. Quaternary Sci., 27, 105-113, 2012c.

Martín, J. and López, P.: Amphibians and reptiles as prey of birds in Southwestern Europe, Smithsonian Herpetological Information Service, 82, 1-43, 1990.

Montori, A.: Amfibis i Rèptils del massis del Garraf. La Sentiu, Quaderns de divulgació, Museu de Gavà, 22, 1-65, 1996.

Naughton, F., Sámchez-Goñi, M. F., Kageyama, M., Bard, E., Dupart, J., Cortijo, E., Despart, S., Malaizé, B., Joly, C., Rostek, F., and Turon, J.-L.: Wet to dry climatic trend in north-western 
Iberia within Heinrich events, Earth Planet. Sci. Lett., 284, 329342, 2009.

Palomo, J. L. and Gisbert, J.: Atlas de los Mamíferos Terrestres de España, 564 pp., Dirección General para la Biodiversidad, Madrid, 2005.

Pleguezuelos, J. M., Márquez, M., and Lizana, L. M.: Atlas y Libro Rojo de los Anfibios y Reptiles de España, 584 pp., Dirección General de Conservación de la Naturaleza - Asociación Herpetológica Española, Madrid, 2004.

Pokines, J.: The Paleoecology of Lower Magdalenian Cantabrian Spain, 198 pp., BAR International Series, Oxford, 1998.

Ramos et al. (Eds.): Fauna Ibérica, vol. 24, Museo Nacional de Ciencias Naturales, Consejo Superior de Investigaciones Científicas, Madrid, 640 pp., 1997.

Reimer, P. J., Baillie, M. G. L., Bard, E., Bayliss, A., Beck, J. W., Blackwell, P. G., Bronk Ramsey, C., Buck, C. E., Burr, G. S., Edwards, R. L., Friedrich, M., Grootes, P. M., Guilderson, T. P., Hajdas, I., Heaton, T. J., Hogg, A. G., Hughen, K. A., Kaiser, K. F., Kromer, B., McCormac, F. G., Manning, S. W., Reimer, R. W., Richards, D. A., Southon, J. R., Talamo, S., Turney, C. S. M., van der Plicht, J., and Weyhenmeyer, C. E.: IntCal09 and Marine09 radiocarbon age calibration curves, 0-50,000 years cal BP, Radiocarbon, 51, 1111-1150, 2009.

Rivera, X., Escoriza, D., Maluquer-Margalef, J., Arribas, O., and Carranza, S.: Amfibis i reptiles de Catalunya, País Valencià i Balears. Lynx Edicions and Societat Catalana d'Herpetologia, Bellaterra and Barcelona, 274 pp., 2011.

Roche, D., Paillard, D., and Cortijo, E.: Constraints on the duration and freshwater release of Heinrich event 4 through isotope modeling, Nature, 432, 379-382, 2004.

Rodríguez, J., Burjachs, F., Cuenca-Bescós, G., García, N., van der Made, J., Pérez González, A., Blain, H.-A., Expósito, I., LópezGarcía, J. M., García Antón, M., Allué, E., Cáceres, I., Huguet, R., Mosquera, M., Ollé, A., Rosell, J., Parés, J. M., Rodríguez, X. P., Díez, C., Rofes, J., Sala, R., Saladié, P., Vallverdú, J., Bennasar, M. L., Blasco, R., Bermúdez de Castro, J. M., and Carbonell, E.: One million years of cultural evolution in a stable environment at Atapuerca (Burgos, Spain), Quaternary Sci. Rev., 30, 1396-1412, 2011.

Salvador, A. (Coord.): Reptiles, in: Fauna Ibérica, edited by: Ramos, M. A. et al., Vol. 10, Museo Nacional de Ciencias Naturales, CSIC, Madrid, 705 p., 1997a.

Sánchez-Goñi, M. F. and d'Errico, F.: La historia de la vegetación y el clima del último ciclo climático (OIS5-OIS1, 140.000-10.000 años BP) en la Península Ibérica y su posible impacto sobre los grupos paleolíticos. Museo y Centro de Investigación de Altamira, Monografías, 20, 115-129, 2005.
Sánchez-Goñi, M. F., Cacho, I., Tron, J.-L., Guiot, J., Sierro, F. J., Peypouquet, J.-P., Grimalt, J. O., and Shackleton, N. J.: Synchroneity between marine and terrestrial responses to millennial scale climatic variability during the last glacial period in the Mediterranean region, Clim. Dynam., 19, 95-105, 2002.

Sanchiz, B., Tejedo, M., and Sánchez-Herráiz, M. J.: Osteological differentiation among Iberian Pelodytes (Anura, Pelodytidae), Graellsia, 58, 35-68, 2002.

Sans-Fuentes, M. A. and Ventura, J.: Distribution patterns of the small mammals (Insectivora, Rodentia) in a transitional zone between the Eurosiberian and the Mediterranean regions, J. Biogeogr., 27, 755-764, 2000.

Sepulchre, P., Ramstein, G., Kageyama, M., Vanhaeren, M., Krinner, G., Sánchez-Goñi, M.-F., and d'Errico, F.: H4 abrupt event and late Neanderthal presence in Iberia, Earth Planet. Sci. Lett., 258, 283-292, 2007.

Sesé, C.: Paleoclimatical interpretation of the Quaternary small mammals of Spain, Geobios, 27, 753-767, 1994.

Sesé, C.: Aportación de los micromamíferos al conocimiento paleoambiental del Pleistoceno Superior en la Región Cantábrica: Nuevos datos y síntesis, Monografias Museo de Altamira, 20, 167-200, 2005.

Sierro, F. J., Hodell, D. A., Curtis, J. H., Flores, J. A., Reguera, I., Colmenero-Hidalgo, E., Bárcena, M. A., Grimalt, J. O., Cacho, I., Frigola, J., and Canals, M.: Impact of iceberg melting on Mediterranean thermohaline circulation during Heinrich events, Paleocenography, 20, PA2019, doi:10.1029/2004PA001051, 2005.

Sommer, R. S. and Nadachowski, A.: Glacial refugia of mammals in Europe: evidence from fossil records, Mammal Rev., 36, 251265, 2006.

Szyndlar, Z.: Fossil snakes from Poland, Acta Zoologica Cracoviensia, 28, 1-156, 1984.

Van der Meulen, A. J.: Middle Pleistocene small mammals from the Monte Peglia (Orvieto, Italy) with special reference to the phylogeny of Microtus (Arvicolidae, Rodentia), Quaternaria, 16, 1-144, 1973.

Vigo, M.: Guia dels mamífers terrestres de Catalunya, Editorial Pórtic: Barcelona, 2002.

Villalta, J. F.: Dos nuevos yacimientos de mamíferos cuaternarios en el macizo del Garraf, Mem. Comun. Instit. Geológ. Prov., 10, 91-93, 1953. 